\title{
Operation Everest II
}

\author{
Peter D. Wagner
}

\begin{abstract}
Wagner, Peter D. Operation Everest II. High Alt. Med. Biol. 11:111-119, 2010.-In October 1985, 25 years ago, 8 subjects and 27 investigators met at the United States Army Research Institute for Environmental Medicine (USARIEM) altitude chambers in Natick, Massachusetts, to study human responses to a simulated 40-day ascent of Mt. Everest, termed Operation Everest II (OE II). Led by Charlie Houston, John Sutton, and Allen Cymerman, these investigators conducted a large number of investigations across several organ systems as the subjects were gradually decompressed over 40 days to the Everest summit equivalent. There the subjects reached a $\dot{\mathrm{VO}}_{2} \mathrm{max}$ of $15.3 \mathrm{~mL} / \mathrm{kg} / \mathrm{min}\left(28 \%\right.$ of initial sea-level values) at $100 \mathrm{~W}$ and arterial $\mathrm{Po}_{2}$ and $\mathrm{PCO}_{2}$ of $\sim 28$ and $\sim 10 \mathrm{~mm} \mathrm{Hg}$, respectively. Cardiac function resisted hypoxia, but the lungs could not: ventilation-perfusion inequality and $\mathrm{O}_{2}$ diffusion limitation reduced arterial oxygenation considerably. Pulmonary vascular resistance was increased, was not reversible after short-term hyperoxia, but was reduced during exercise. Skeletal muscle atrophy occurred, but muscle structure and function were otherwise remarkably unaffected. Neurological deficits (cognition and memory) persisted after return to sea level, more so in those with high hypoxic ventilatory responsiveness, with motor function essentially spared. Nine percent body weight loss (despite an unrestricted diet) was mainly (67\%) from muscle and exceeded the $2 \%$ predicted from energy intake-expenditure balance. Some immunological and lipid metabolic changes occurred, of uncertain mechanism or significance. OE II was unique in the diversity and complexity of studies carried out on a single, courageous cohort of subjects. These studies could never have been carried out in the field, and thus complement studies such as the American Medical Research Expedition to Everest (AMREE) that, although more limited in scope, serve as benchmarks and reality checks for chamber studies like OE II.
\end{abstract}

Key Words: ventrical function; pulmonary vascular response; pulmonary gas exchange

\section{Introduction}

$\mathbf{I}_{\mathrm{H}}^{\mathrm{N}}$ N THE FALl OF 1985, ALMOST EXACTLy 25 YeARs Ago, Charlie Houston, John Sutton, and Allen Cymerman (as principal investigators) convened a group of 9 young, adult, normal male volunteer research subjects and 27 scientific investigators (Houston et al., 1991) at USARIEM, in Natick, Massachusetts. One investigator was Jack Reeves, who played an especially prominent role in the execution of what was to become known as Operation Everest II (OE II). They are shown in Fig. 1 together with Richard Riley, who was, along with Charlie Houston, a central figure in OE I, the predecessor to OE II. Sadly, Richard, Charlie, John, and Jack have left us, and this review is written in their honor.

The objective of OE II was to study a wide array of human biological responses along the way to, and then at, extreme simulated altitude as the subjects were gradually decompressed to a barometric pressure giving the equivalent in- spired $\mathrm{Po}_{2}$ of the summit of Mt. Everest, about $43 \mathrm{mmHg}$. The decompression profile is shown in Figure 2.

OE II investigators studied cardiovascular, respiratory, metabolic, muscle, hematological, immunological, and neural responses (awake and asleep) in the 8 subjects. To date, these studies have resulted in at least 33 primary peer-reviewed research papers and 15 (16 if the present effort is included) reviews.

\section{Unique elements of $O E$ II}

Given that there have been many research studies at high altitude carried out by many groups of investigators, both before and since, perhaps the primary question is what was unique about OE II. The uniqueness lies in two factors: (1) the remarkable breadth of interdisciplinary studies conducted both in parallel and in series by the large number of researchers on the same subject cohort and (2) the ability 

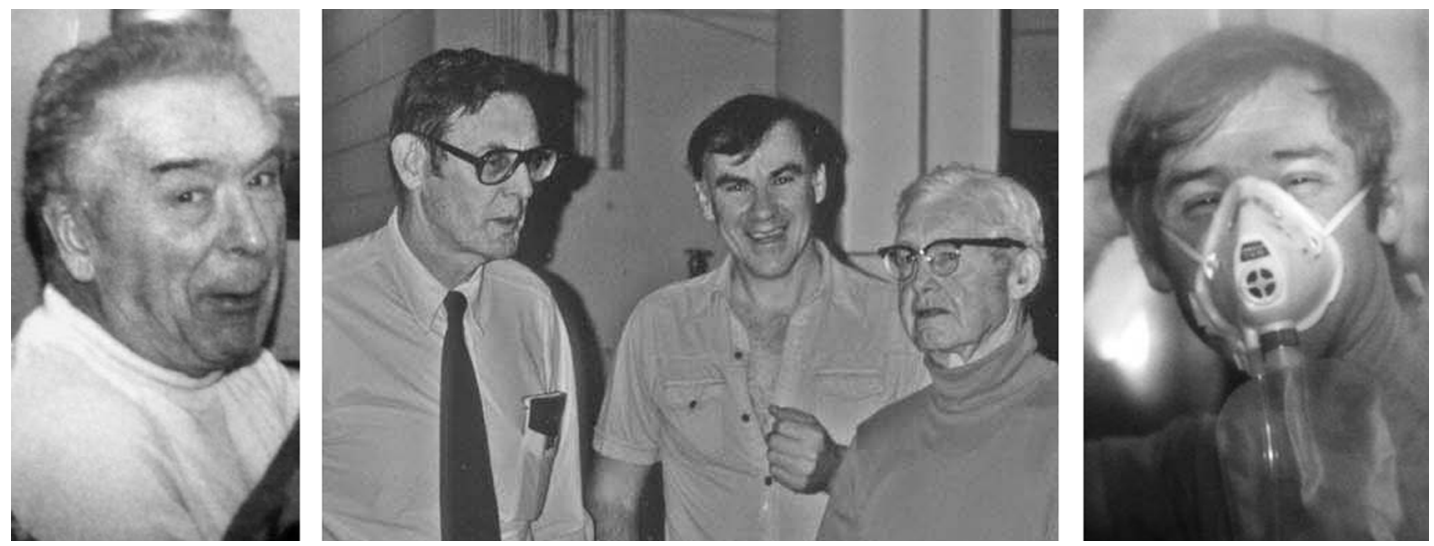

FIG. 1. Left to right: Charlie Houston, Jack Reeves, John Sutton, Richard Riley, and Allen Cymerman. Photos all taken at USARIEM during OE II, October 1985.

to make so many invasive and/or technically demanding measurements requiring catheter placement, tissue biopsy, complex electrical signal acquisition, and the like. The resulting accomplishments of OE II could never have been made in the field. For example, placement of both a systemic arterial and pulmonary arterial catheter was accomplished, allowing blood sampling and pressure measurements to be performed during maximal exercise, not just at sea level at the start of OE II, but also at intermediate stops: $\mathrm{P}_{\mathrm{B}} 347 \mathrm{mmHg}$ $(\sim 20,000 \mathrm{ft}, \sim 6100 \mathrm{~m}) ; \mathrm{P}_{\mathrm{B}} 282 \mathrm{mmHg}(\sim 25,000 \mathrm{ft}, \sim 7600 \mathrm{~m})$; and the summit equivalent: $P_{B} 253 \mathrm{mmHg}(\sim 29,000 \mathrm{ft}$, $\sim 8848 \mathrm{~m})$. Stated altitudes are from the International Civil Aviation Organization (ICAO) tables and are slightly lower than occur on Mt. Everest at the same $P_{B}$ (West et al., 1983). Actual chamber barometric pressure on the "summit" was set to only $240 \mathrm{mmHg}$ to compensate for the presence of an $\mathrm{FIO}_{2}$ in the chamber of 0.22 . This was done to keep chamber $\mathrm{PIO}_{2}$ at $43 \mathrm{mmHg}$, equal to the actual summit $P_{B}$ of $253 \mathrm{mmHg}$ breathing air. For simplicity in this review, "summit" $\mathrm{P}_{\mathrm{B}}$ in $\mathrm{OE}$ II will be referred to as $253 \mathrm{mmHg}$.

\section{Chamber studies and field expeditions}

It is probably useful to deal here with the inevitable argument about chamber versus field studies of altitude-related physiology and then to set that aside to allow focus on what $O E$ II achieved. There is no denying that field studies examine the "real thing." They encompass multidimensional insults to the body: hypoxia, exercise, cold, wind, stresses such as anxiety, fear, potential nutritional insufficiencies, potentially interrupted sleep, coping with injuries, illnesses, and so on. Rewards of course occur as well: the sense of accomplishment, the benefits of camaraderie, and the inherent beauty of the mountains. The insults additional to hypoxia may well affect the primary research, which focuses mostly on hypoxia, and produce results that might be different from those at similar hypoxic levels, where the above additional stresses might differ. They (weather, injury, illness) may even result in failure of the expedition. Additionally, not all subjects can make the summit of Everest breathing only ambient air, and time spent breathing oxygen may give rise to intermittent hypoxic exposure that may

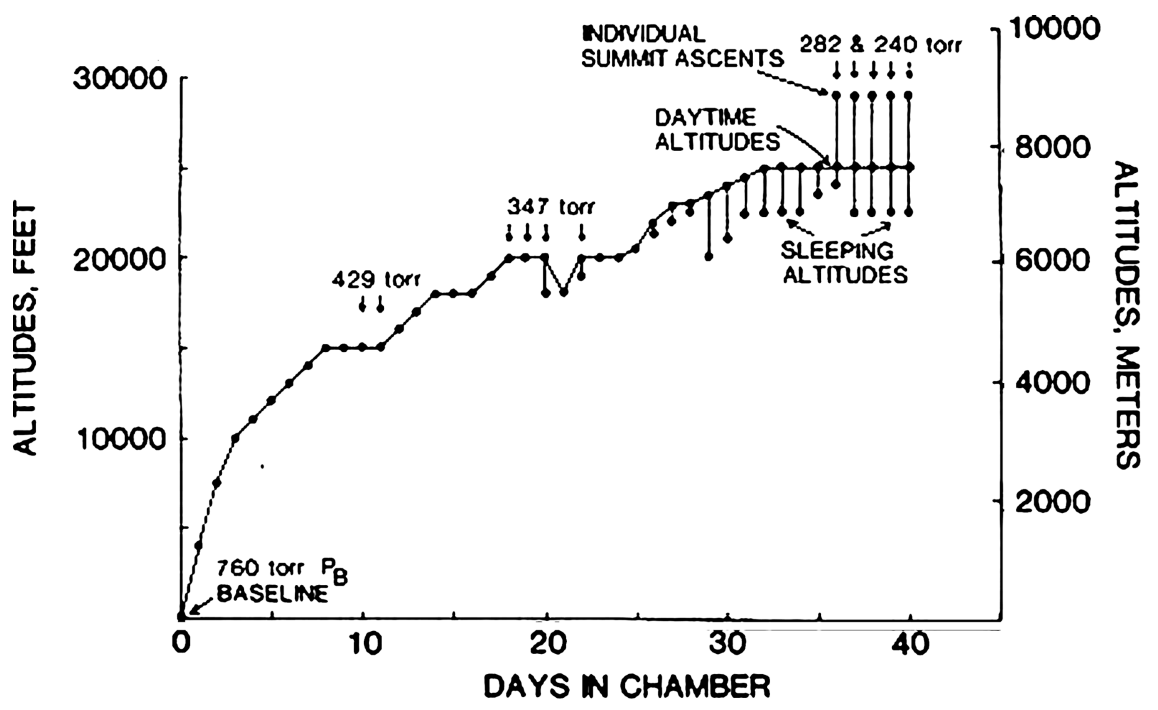

FIG. 2. Decompression schedule showing simulated altitudes (calculated from the ICAO standard atmospheric pressurealtitude relationship) as a function of time. 
produce separate physiological effects not encountered in chamber studies, where ambient air is always breathed. Similarly, in field studies requiring ascents and descents before the summit is reached, altitude is not gained in a monotonic fashion, and this too may alter the kinetics of response compared with what would be seen in a steadily progressive ascent. That said, in OE II, some nights involved slight "descent."

Chamber studies generally simulate only the hypoxia. To a lesser extent, they include highly regulated exercise, different from climbing, on an ergometer in a cramped environment, and different stresses: suffering the intrusions of a horde of investigators (who are bent on catheterizing, sampling, and measuring all they can with procedures that have potential risk), boredom, forced close contact with fellow subjects, and confinement within a small, sealed chamber. There is no climbing accomplishment, and the beauty of the mountains is certainly absent. On the other hand, there is a bed to sleep on, a toilet to sit on, showers, good food always at hand, and, in case of illness, the chamber door can be opened and the subject managed within seconds. The real benefit in chamber studies is that vastly more complex research can be performed than could be managed in the field and that control of extraneous factors such as cold or injury can be assured.

Field and chamber studies clearly have their pros and cons. This writer believes in their complementarity: both are valuable. To the extent that hypoxia dominates the findings, they can be similar, but the other differences need to be allowed for when results are examined. For OE II, a limitation as a chamber study was the speed of decompression. As Fig. 2 shows, subjects "summited" within 40 days, quite a bit faster than the ascent profile used in AMREE. One consequence of the rapid decompression profile in OE II was that, when passing through 20,000 ft, most subjects developed evidence of high altitude pulmonary edema (HAPE), and the "ascent" had to be interrupted with nighttime "descents" until subjects returned to normal. Time-dependent altitude responses may well have been affected by the rapid schedule, and, indeed, much has been written about the likely lesser degree of ventilatory acclimatization in OE II than in actual Everest ascent studies such as AMREE, described in this volume by Dr. West (West, 2010). That said, it will be pointed out later in this review that the similarities seem greater than the differences for many variables. Another limitation of OE II was that, because of the frequent need for taking blood by many of the investigators, the hypoxiainduced increase in $\mathrm{Hb}$ concentration was somewhat attenuated, average values increasing from 13.3 to only $16.9 \mathrm{~g} / \mathrm{dL}$ (Groves et al., 1987). In AMREE, for example, Hb concentration averaged $18.4 \mathrm{~g} / \mathrm{dL}$ at $8050 \mathrm{~m}(n=2)$ (Winslow et al., 1984). To the extent that high hemoglobin at altitude is physiologically beneficial, which is not necessarily agreed to be the case (Calbet et al., 2002), OE II probably produced conservative results, especially in the context of maximal exercise and cardiac function.

Suffice it to say that OE II produced many historic firsts, and these and other important findings are now highlighted, with apologies to the original authors, in the remainder of this review. The order of presentation should not be assumed to reflect relative importance; further, it should be recognized that it is not possible within the allotted space to describe any of the results in detail or how the changes progressed with every step of increasing decompression. Indeed, not every finding can be discussed here. The focus will generally be on the most positive and novel findings, especially at the summit equivalent. Fifteen of the 30 primary research publications generated by OE II are cited in the text; the remaining 15 appear separately in the reference list along with 5 review articles.

\section{Exercise capacity}

As has been known for many years, exercise capacity, measured as $\dot{\mathrm{V}}_{2} \mathrm{max}$, falls progressively with altitude. In the moderately fit $\mathrm{OE}$ II subjects, $\mathrm{VO}_{2}$ max declined from an average of $4.13 \mathrm{~L} / \mathrm{min}(49.1 \mathrm{~mL} / \mathrm{kg} / \mathrm{min})$ at $370 \mathrm{~W}$ at sea level to $1.17 \mathrm{~L} / \mathrm{min}(15.3 \mathrm{~mL} / \mathrm{kg} / \mathrm{min})$ at $100 \mathrm{~W}$ at the "summit." Figure 3 shows the pattern of decline. The data are remarkably close to those of Pugh and colleagues (1964) across the entire altitude domain. At extreme altitude, the data are also indistinguishable from those of AMREE (West et al., 1983), although the AMREE subjects had higher sea-level values of $\dot{\mathrm{V}}_{2} \mathrm{max}$.

At the "summit", $\dot{V}_{2}$ max was just $28 \%$ of initial sea-level values, indicating a loss of $72 \%$ in exercise capacity. Most but not all of this is owing to the direct effect of hypoxia on oxygen transport. However, some is caused by loss of muscle mass and possibly loss of fitness after being confined to a small pressure chamber for 40 days. $\dot{\mathrm{V}} \mathrm{VO}_{2}$ max at sea level was measured within hours of "descent" and found to be $3.30 \mathrm{~L} /$ $\min (42.5 \mathrm{~mL} / \mathrm{kg} / \mathrm{min})$, which is $80 \%$ of the prestudy values. This gives insight into the relative contributions of direct hypoxic effects versus these other factors, because direct effects would be instantly reversible on descent, whereas the other factors would take time and probably retraining to recover. Thus, compared with immediate post-OE II values, hypoxia equivalent to the Everest summit reduced $\dot{\mathrm{V}} \mathrm{Vo}_{2} \mathrm{max}$ by $64 \%$, explaining all but about $10 \%$ of the $72 \%$ loss from the prestudy values indicated above. Thus, loss of fitness and/or muscle mass during the 40 days was a minor contributor to reduced exercise capacity.

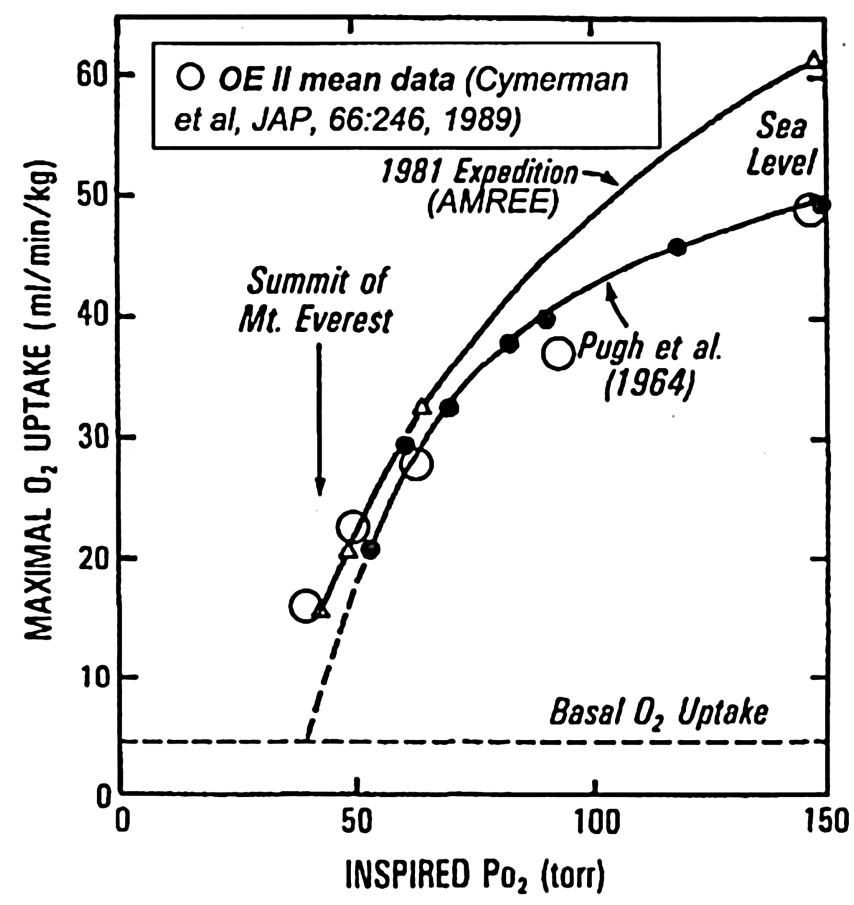

FIG. 3. Maximal $\mathrm{O}_{2}$ uptake against inspired $\mathrm{PO}_{2}$. Open circles: OE II data superimposed upon the relationship depicted in West (2010). 


\section{Left ventricular function}

It is well known that cardiac output at maximal exercise is lower in chronic hypoxia than at sea level. This was found in OE II also. At maximal exercise at $\mathrm{P}_{\mathrm{B}}=760,347,282$, and $253 \mathrm{mmHg}$, cardiac output averaged 24.2, 20.3, 15.9, and $16.1 \mathrm{~L} / \mathrm{min}$, respectively (Sutton et al., 1988). Regarding the similarity of data at the two highest altitudes, recall that the measurements at $253 \mathrm{mmHg}$ occurred within $1 \mathrm{~h}$ of leaving $282 \mathrm{mmHg}$ and thus represent an acutely added degree of hypoxia. Values at 347 and $282 \mathrm{mmHg}$, on the other hand, reflect data after several days at these altitudes.

In OE II, we attempted to investigate, at least in part, the cause of this fall in maximal cardiac output. Potential explanations include (1) hypoxic ventricular dysfunction, (2) reduced venous return (potentially from hypovolemia) and thus lower ventricular filling pressures, (3) altered autonomic input to the heart, or (4) reduced demand for blood flow secondary to reduced $\mathrm{O} 2$ demand from other effects of hypoxia on $\mathrm{O}_{2}$ transport. Figure 4, using data from Reeves and colleagues
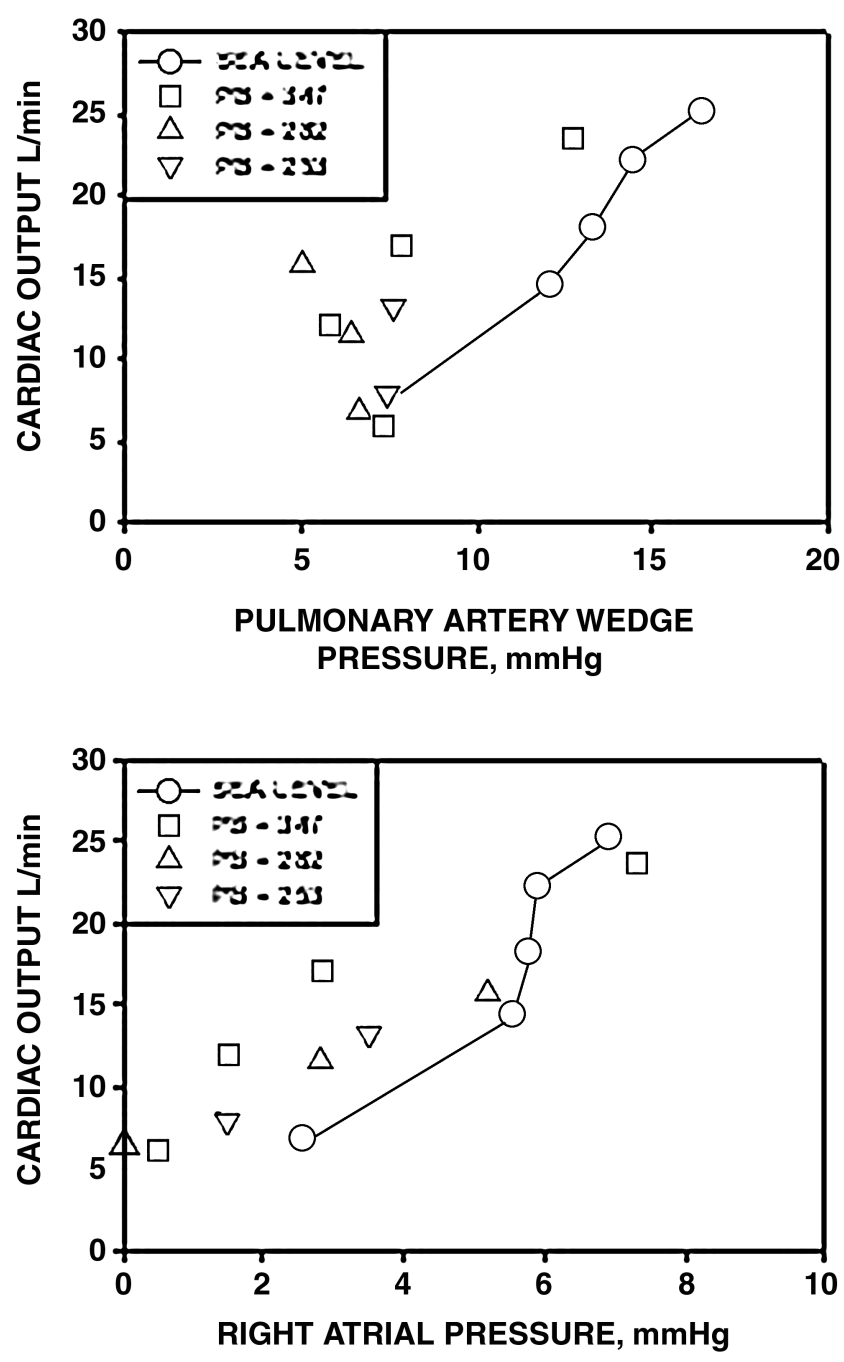

FIG. 4. Cardiac output from rest to exercise as a function of left and right atrial mean pressures (mean data). With increasing altitude, there is no suggestion that cardiac output is lower at any filling pressure. If anything, the opposite is seen (Reeves et al., 1987).
(1987), shows that, whether related to left or right atrial pressures as estimates of their respective ventricular filling pressures, cardiac output is if anything higher, and not lower, at any given filling pressure as altitude is gained. The same is found when stroke volume is examined rather than cardiac output. This occurs in the face of increasing average systemic vascular resistance with increasing altitude (Reeves et al., 1987). In fact, using echocardiography, Suarez and colleagues (1987) found that ventricular function at all altitudes was similar to that at sea level, or even slightly enhanced.

No interventions with fluid volume expansion or autonomic interruption were done in OE II to directly explore the possible roles of reduced filling pressures or altered autonomic control, respectively, but the data clearly showed that cardiac function was not at all impaired at any altitude. Thus, hypoxic impairment of cardiac function was not seen and cannot explain the reduction in maximal cardiac output. In this chamber study with good nutritional support, hypovolemia sufficient to reduce cardiac output by one-third seems unlikely, and other studies have shown that restoring the reduced maximal heart rate to sea-level values by vagal inhibition (Boushel et al., 2001) does not increase maximal cardiac output at altitude. This leaves the most likely explanation as hypothesis (4) above: reduced metabolic demand. What is clear is that the heart functions well at an arterial $\mathrm{Po}_{2}$ of less than $30 \mathrm{mmHg}$ even during exercise.

\section{Right ventricular function and pulmonary vascular responses}

Right ventricular function was also well preserved at altitude in spite of substantial pulmonary arterial hypertension (e.g., mean pressure $34 \mathrm{mmHg}$ at $\mathrm{P}_{\mathrm{B}} 282 \mathrm{mmHg}$ (Groves et al., 1987). Right ventricular filling pressures were not elevated, and there was no evidence of right heart failure.

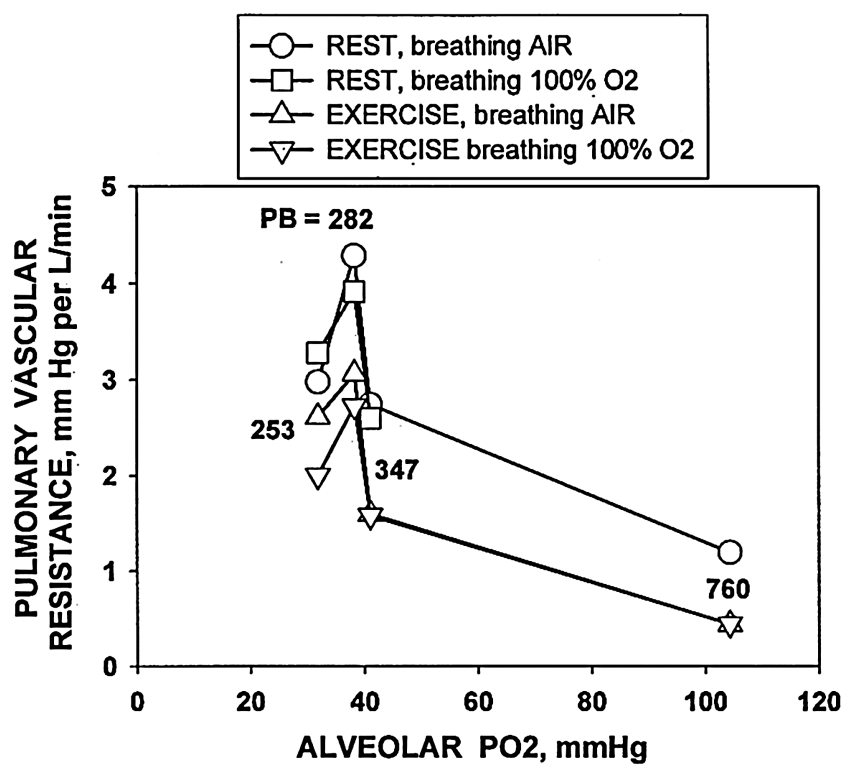

FIG. 5. Mean values for pulmonary vascular resistance (PVR) at rest and exercise as a function of altitude (represented by air-breathing alveolar $\mathrm{Po}_{2}$ ). PVR is unresponsive to $100 \% \mathrm{O}_{2}$ at altitude, both at rest and during exercise, but is lower during exercise at each altitude. The reduction in PVR on the "summit" compared with $282 \mathrm{mmHg}$ appears consistent, but remains unexplained (Groves et al., 1987). 
Hypoxic pulmonary vasoconstriction is a well-established consequence of altitude, resulting in pulmonary arterial hypertension and, eventually, right ventricular hypertrophy. Pulmonary vascular resistance indeed rose progressively with altitude (Fig. 5), except during the acute hypoxic change from $P_{B} 282 \mathrm{mmHg}$ to the "summit" at $P_{B} 253 \mathrm{mmHg}$, which, as explained, happened over the course of $30 \mathrm{~min}$. This was found both at rest and during exercise. Acute (about $30 \mathrm{~min}$ ) administration of $100 \% \mathrm{O}_{2}$ failed to alter pulmonary vascular resistance (PVR) at rest or during exercise, yet just a few minutes of exercise itself clearly lowered PVR. This may be because hypoxic remodeling of small pulmonary arteries is not rapidly reversible by oxygen breathing, whereas, during exercise, pulmonary capillary recruitment and distension occur and allow resistance to fall. The curious drop in PVR under all conditions on the "summit" (Fig. 5) was unanticipated and remains unexplained. One hypothesis is that altered autonomic function following further hypoxia associated with acute decompression to the "summit" is somehow involved.

\section{Pulmonary gas exchange}

Pulmonary gas exchange can be examined in several ways. The major response to hypoxia is well known to be hyperventilation, and the degree of hyperventilation is reflected in alveolar $\mathrm{Po}_{2}$ and $\mathrm{PCO}_{2}$. Figure 6 shows the OE II data for these two variables under resting conditions (Sutton et al., 1988) superimposed on the equivalent figure from West (2010). At sea level, the OE II subjects hyperventilated, likely because the data were collected immediately before the subjects were to undertake a graded exercise test to $\mathrm{Vo}_{2}$ max. This probably explains the lower $\mathrm{PCO}_{2}$ than in the other data shown in the Fig. 6. However, as Fig. 4 also shows, at all altitudes except that at the "summit," OE II data are indistinguishable from those of both AMREE and Rahn and Otis (1949). Of interest, it can be seen that on the OE II "summit" alveolar $\mathrm{Po}_{2}$ was slightly lower and $\mathrm{PCO}_{2}$ slightly higher than found in AMREE. The pattern of alveolar gas tensions across all studies in Fig. 4 suggests that the rapid



FIG. 6. $\mathrm{O}_{2}-\mathrm{CO}_{2}$ diagram showing alveolar $\mathrm{PO}_{2}$ and $\mathrm{PCO}_{2}$ with increasing altitude. Open circles: OE II data superimposed on the relationship depicted in West (2010). decompression schedule of OE II did in fact not measurably impair the resting ventilatory response to hypoxia up to $7600 \mathrm{~m}$. As regards the summit data, it should be noted that in AMREE the data were obviously collected only after the subject had reached the summit, having taken many hours, used supplementary $\mathrm{O}_{2}$, and expended much effort. In OE II, the "summit" data were obtained after a roughly 30-min decompression from $\mathrm{P}_{\mathrm{B}} 282 \mathrm{mmHg}(7600 \mathrm{~m})$ throughout which the subjects were at rest, breathing ambient air. It should also be pointed out that it is well known that the range of hypoxic ventilatory responsiveness in the normal population is wide. Thus, since both data sets come from small subject numbers and were collected following very different "ascent" histories, the summit differences should not be overinterpreted. In addition to alveolar $\mathrm{PO}_{2}$ and $\mathrm{PCO}_{2}$ measurements, both hypoxic and hypercapnic ventilatory responses were assessed during ascent to $P_{B}=305 \mathrm{mmHg}$ and found to be exaggerated as altitude was gained (Schoene et al., 1990).

Gas exchange is also affected by ventilation-perfusion ( $\dot{\mathrm{V} a} / \dot{\mathrm{Q}})$ inequality, which was directly assessed in OE II (Wagner et al., 1987b). The basic parameter of inequality used is the second moment of the Va/Q distribution, called LOG SDQ. In normal resting subjects at sea level, LOG SDQ averages 0.30 to 0.45 , with the $95 \%$ upper confidence limit at 0.60 (Wagner et al., 1987a). In the OE II subjects, resting LOG SDQ on the "summit" averaged 1.0. Put in perspective, this is the value expected in patients with moderate lung disease. Inequality increased with exercise at each altitude studied, and in some, exercise LOG SDQ was extraordinarily high at over 2.0, a level previously seen only in patients in respiratory distress and failure in an intensive care unit. It is hard to imagine anything except high altitude pulmonary edema as the explanation for this marked $\dot{\mathrm{V} a} / \dot{Q}$ inequality. However, even marked inequality at extreme altitude has little effect on the alveolar-arterial $\mathrm{Po}_{2}$ difference owing to the shape and slope of the $\mathrm{O} 2-\mathrm{Hb}$ dissociation curve (Wagner, 2001).

Finally, alveolar-capillary diffusion limitation has been predicted to have a major effect on $\mathrm{O}_{2}$ transfer and arterial saturation, increasing as altitude is gained (West and Wagner, 1980). This was indeed found to be the case in OE II (Wagner et al., 1987b), where on the summit at maximal exercise, diffusion limitation accounted for almost all the 6-mm $\mathrm{Hg}$ alveolar-arterial $\mathrm{Po}_{2}$ difference $\left(\mathrm{AaPo}_{2}\right)$. Although $6 \mathrm{mmHg}$ may seem small, arterial $\mathrm{Po}_{2}$ was just $28 \mathrm{mmHg}$ (alveolar therefore being $34 \mathrm{mmHg}$ ), resulting in about a $15 \%$ reduction in arterial $\mathrm{O}_{2}$ saturation.

As a result of alterations in $\mathrm{PIO}_{2}, \dot{\mathrm{Va}} / \dot{\mathrm{Q}}$ inequality, and diffusion limitation, directly measured arterial $\mathrm{PO}_{2}$ and $\mathrm{PCO}_{2}$ at rest on the "summit" were 30.3 and $11.2 \mathrm{mmHg}$, respectively $(n=6)$. During exercise at $60 \mathrm{~W}$, they were 27.8 and $10.7 \mathrm{mmHg}$, respectively $(n=5)$, and at $120 \mathrm{~W}$, they were 27.6 and $9.6 \mathrm{mmHg}$, respectively $(n=3)$. These incredible numbers leave one unable to imagine what the lowest nondamaging arterial $\mathrm{PO}_{2}$ might be in humans, given enough time to "acclimatize." Note in this issue that Grocott and colleagues (2010) report on arterial blood gas measurements in the Caudwell Xtreme Everest Expedition and found mean values of $24.6 \mathrm{mmHg}\left(\mathrm{Po}_{2}\right)$ and $13.3 \mathrm{mmHg}\left(\mathrm{PCO}_{2}\right)$ at $8400 \mathrm{~m}$ on descent from the summit. $\mathrm{Po}_{2}$ was lower and $\mathrm{PCO}_{2}$ was higher than found during OE II, but the small subject numbers $(n=4)$ and different circumstances (extreme effort on the real climb, intermittent use of supplemental $\mathrm{O}_{2}$ ) make it difficult to interpret small differences. 


\section{Acid-base balance}

Although not a major focus of OE II, acid-base changes with altitude were examined in the course of exercise studies when arterial catheters were in place (sea level and altitudes corresponding to $\mathrm{P}_{\mathrm{B}} 429,347,282$, and $253 \mathrm{mmHg}$ ). Measured arterial $\mathrm{pH}$ at rest did not rise as much as suggested by AMREE data, which infer a summit $\mathrm{pH}$ of between 7.7 and 7.8 based on measured values of alveolar $\mathrm{PCO}_{2}$ and base excess (West, 2010). At sea level and the above four altitudes, resting arterial $\mathrm{pH}$ values averaged 7.43, 7.46, 7.50, 7.53, and 7.56 (Sutton et al., 1988). Corresponding values of base excess were $-1,-4,-5,-9$, and $-9 \mathrm{mEq} / \mathrm{L}$. Except at the summit, the reasons for any differences in arterial $\mathrm{pH}$ between OE II measurements and AMREE predictions cannot lie in different arterial $\mathrm{PCO}_{2}$ values (see Fig. 6) and so must reflect differences in renal compensation. However, the summit differences may be contributed to by higher $\mathrm{PCO}_{2}$ (of $11 \mathrm{mmHg}$ ) in OE II. Had arterial $\mathrm{PCO}_{2}$ been $8 \mathrm{mmHg}$ as in AMREE, measured $\mathrm{pH}$ would have been around 7.65, rather than 7.56, as measured. However, this is still somewhat less than the AMREE prediction.

\section{Peripheral gas exchange}

Peripheral gas exchange was not a topic of research proposed for OE II. Nonetheless, it was remarkable to find how high mixed venous $\mathrm{PO}_{2}\left(\mathrm{PvO}_{2}\right)$ was during maximal exercise at altitude. At sea level, $\mathrm{PvO}_{2}$ was $18.5 \mathrm{mmHg}$ at $\dot{\mathrm{V}} \mathrm{O}_{2}$ max. On the "summit," it was still $13.8 \mathrm{mmHg}$. In part, this may have reflected a higher $\mathrm{Po}_{2}$ in venous blood returning from tissues other than heart and muscles, but it is hard to imagine that this can explain all the residual $\mathrm{O}_{2}$ in mixed venous blood. A chance observation that has led to the development of a comprehensive treatment of peripheral $\mathrm{O}_{2}$ exchange in muscle (Wagner, 1996) would never have been made without measurement of mixed venous $\mathrm{Po}_{2}$ values at $\dot{\mathrm{V}}_{2}$ max at several altitudes as OE II progressed, a data set never before available. It was found that with increasing altitude not only did $\dot{\mathrm{V}}_{2}$ max fall progressively, but so too did $\mathrm{Po}_{2}$ of mixed venous blood $\left(\mathrm{PvO}_{2}\right)$. This per se may not seem surprising, but what caught our attention was that the drop in $\mathrm{PvO}_{2}$ was closely proportional to that in $\dot{\mathrm{V}}_{2}$ max. Since $\mathrm{PvO}_{2}$ can be taken to reflect the diffusion gradient for $\mathrm{O}_{2}$ between muscle blood and muscle mitochondria, the proportional relationship was proposed as evidence that diffusive movement of $\mathrm{O}_{2}$ between blood and mitochondria in muscle was diffusion limited, thus contributing to limitation of $\dot{\mathrm{V}}_{2}$ max at altitude. This hypothesis spawned an entire new research program that has indeed confirmed the importance of muscle $\mathrm{O}_{2}$ transport limitation by diffusion as a major factor limiting maximal $\dot{\mathrm{V}}_{2}$ in health, both at sea level and at altitude (also explaining the high $\mathrm{Po}_{2}$ values in venous blood) ( Roca et al., 1989; Hogan et al., 1991; Richardson et al., 1998).

\section{Skeletal muscle function}

The great interest in $\mathrm{O}_{2}$ transport at altitude occurs partly because of the $\mathrm{O}_{2}$ needs of the skeletal muscles, which need $\mathrm{O}_{2}$ to allow climbing in the first place. Thus, studying skeletal muscle adaptation to extreme altitude became a focus of OE II. Green and colleagues (1989b) biopsied vastus lateralis at sea level pre-OE II, at $\mathrm{P}_{\mathrm{B}} 380$ and also $282 \mathrm{mmHg}$, and finally post$\mathrm{OE}$ II at sea level. Somewhat surprisingly, they found no change in major muscle metabolic enzyme maximal activities from pre-OE II to $282 \mathrm{mmHg}$, equivalent to $\sim 7600 \mathrm{~m}$ or $\sim 25,000 \mathrm{ft}$. Enzymes assessed reflected the major pathways: fatty acid $\beta$-oxidation, glycogenolysis, glycolysis, the citric acid cycle, glucose phosphorylation, and high-energy phosphate transfer. However, the data obtained on return to sea level indicated significantly lower activities for several of the key enzymes, and examination of the progression of enzyme activities over the entire project reveals changes that allow one to suggest that there may have been increased activity levels of some enzymes at the first altitude measured $\left(P_{B}\right.$ $380 \mathrm{mmHg}$ ), which then fell with increasing altitude and time. This is a hypothesis, not a conclusion. However, the findings are greatly complicated by the lessening physical activity of the subjects as altitude was gained. There is thus a combination of progressive hypoxia, less activity over time, and alkalosis as well. To determine whether the hypoxia of extreme altitude alone alters metabolic potential would require a control group matched for physical activity and acid-base state at the least. Green and colleagues (1989b) also found that extreme altitude did not lead to differences in glycogen stores or usage during exercise and that exercise-induced reductions of adenosine triphosphate (ATP) and creatine phosphate (high-energy compounds) were similar between sea level and extreme altitude.

OE II was a unique opportunity to gain further insight into the lactate paradox (the observations that, in spite of extreme hypoxia, blood lactate at a given exercise level rises less after spending time at altitude than immediately on ascent, and that blood lactate levels at exhaustion are progressively lower, and not higher, as altitude is gained). From muscle biopsies, it was found that muscle lactate levels at exhaustion were greatly reduced at altitude, compatible with lower power outputs (Green et al., 1989a). Thus, low blood lactate levels appear to reflect low muscle lactate levels.

Muscle structure was affected (MacDougall et al., 1991). The cross-sectional area of both type I and II fibers was significantly reduced, compatible with the well-known propensity for loss of muscle mass and body weight at extreme altitude. Muscle capillary density was increased, but only as a result of the loss of fiber area. The number of muscle capillaries was not altered. This is surprising insofar as muscle angiogenesis is believed to be driven at least in part by hypoxia-sensitive genes such as VEGF, possibly activated by HIF-1 $\alpha$ (Forsythe et al., 1996).

Neuromuscular function was also studied in OE II (Garner et al., 1990) using a small- muscle mass group (ankle dorsiflexors). Effects of extreme altitude were mild to nonexistent, with force generation capacity and neuromuscular transmission preserved. There was evidence of slightly greater muscle fatigability.

In all, muscle changes other than loss of muscle mass were surprisingly mild or absent.

\section{Neurological function}

Although neuromuscular function was preserved (see above), neuropsychological testing revealed clear deficits resulting from exposure to extreme hypoxia in OE II. Hornbein and colleagues (1989) found persisting visual and verbal longterm memory deficits after subjects had returned to sea level. A provocative finding, also noted by Hornbein to be evident in the AMREE data, was that subjects with higher hypoxic 
ventilatory responsiveness displayed greater neuropsychological deficits. This was not expected, as higher ventilation should lead to greater arterial and thus cerebral oxygenation. However, Hornbein proposed that the greater degree of hypocapnia associated with higher ventilation may have caused sufficient cerebral vasoconstriction to more than offset the higher arterial $\mathrm{PO}_{2}$ and thus reduce overall cerebral $\mathrm{O}_{2}$ availability. This remains to be settled. Kennedy and colleagues (1989) also studied central nervous system function during OE II and found cognitive impairment (impaired pattern comparison and grammatical reasoning). Motor function was minimally affected. Finally, also in OE II, Kobrick and colleagues (1988) found visual contrast sensitivity unaffected by altitude.

\section{Immunological function}

A variety of in vivo and in vitro immune alterations were identified from 7 subjects during the ascent in OE II. Peripheral blood IgA and IgM immunoglobulin levels were increased at $25,000 \mathrm{ft}$, whereas in vitro peripheral blood mononuclear cell spontaneous and pokeweed mitogen-stimulated IgG/A/M production was unchanged. Spontaneous and stimulated in vitro production of interferon and natural killer (NK) cytotoxicity against the K562 cell line was unimpaired, and no increase in the generation of antinuclear antibodies was observed in the peripheral blood from any subject. Mucosal immunity was unimpaired, as determined by nasal pharyngeal washing measurements of IgA and lysozyme levels. In contrast, significant impairment of in vitro $T$ cell function was documented by a $50 \%$ reduction in PHA-stimulated protein synthesis at $24 \mathrm{~h}$ of culture, followed by a $33 \%$ reduction in proliferation by $72 \mathrm{~h}$ by thymidine uptake. Simultaneous peripheral blood mononuclear cell subset analysis by flow cytometry indicated an increase in circulating monocytes without changes in B cells or $\mathrm{T}$ cell subsets. These findings suggest hypoxic exposure most likely alters normal immune regulation and function, $\mathrm{T}$ cell function more than B cell, or mucosal immunity through unidentified stress-mediated alterations in normal adaptive immunity, possibly mediated by monocyte-derived cytokines. Similar in vivo and in vitro immunologic alterations have been observed from subjects exposed to other environmental stressors, including space flight and military and mountaineering expeditions (Meehan et al., 1992; Meehan et al., 2001).

\section{Metabolic and hormonal responses; nutrition and body composition}

It has long been known that spending time at extreme altitude results in loss of body weight. This may come from reduction in fat mass, fat-free mass, or both, and causative factors may include hypoxia, poor diet, malabsorption, increased physical activity, dehydration, or stresses such as those mentioned in the introduction. In OE II, some of these factors could be excluded. Rose and colleagues (1988) showed that subjects lost $9 \%$ of their body weight on a palatable ad lib diet that included more than $3000 \mathrm{kcal} /$ day of their favorite foods. In spite of food availability, intake fell progressively and substantially with altitude, from 3136 to $1789 \mathrm{kcal} /$ day. However, even this reduction in intake, given the levels of physical activity $(\sim 715 \mathrm{kcal})$, should have caused only a $2 \%$ weight loss, according to Rose. Dehydration can contribute to weight loss, but a rough fluid balance study (fluid intake vs. urine output) showed the subjects were maintaining hydration; but fluid losses from feces, hyperventilation, and excessive sweating were not measured. Computed tomography scans showed most of the weight was lost from fat-free $(67 \%)$ sources, especially muscle. Malabsorption was not assessed, but these data suggest that hypoxia alone explains the majority of the findings.

Young and colleagues (1989) measured plasma lipid and certain hormonal profiles and found substantial changes over the course of OE II, although their mechanisms, significance, and longevity remain to be established. Fasting cholesterol levels fell by about $30 \%$ and triglyceride and insulin levels increased twofold, without changes in glucagon. Norepinephrine levels increased by a factor of 3 (with no change in epinephrine). We can only speculate that increased metabolism might have caused the weight loss.

\section{Conclusions}

In conclusion, OE II was a remarkable study, unique in its breadth and depth of topics studied and methods used. We found that at extreme altitude the heart does well, but the lungs do not (although the lungs can still support massive hyperventilation, there is substantial ventilation-perfusion inequality and, during exercise, diffusion limitation). Renal compensation for hypocapnia is far from complete after 40 days of progressive hypoxia. The muscles atrophy, accounting for most of the weight loss, but the hypoxia does not promote muscle angiogenesis or metabolic adaptations sufficient to overcome the loss of oxygen. The blood shows evidence of altered lipid metabolism and immune function. Cognitive function is impaired, but at the end of the day, normal subjects can still function and even exercise at $100 \mathrm{~W}$ (the equivalent of a moderately slow horizontal walk at sea level), in spite of an arterial $\mathrm{Po}_{2}$ of less than $30 \mathrm{mmHg}$.

\section{Acknowledgments}

This work was supported by the National Institutes of Health P01 HL091830. The author wishes to thank Dr. Madeleine Rose and Dr. Richard Meehan for help in describing the nutritional and immunological findings in OE II, respectively.

\section{Disclosures}

The author has no conflicts of interest or financial ties to disclose.

\section{References}

Boushel R., Radegran G., Calbet J.A.L., Sondergaard H., Wagner P.D., and Saltin B. (2001). Parasympathetic neural activity accounts for the lowering of exercise heart rate at high altitude. Circulation. 104:1785-1791.

Calbet J.A.L., Radegran G., Boushel R., Sondergaard H., Saltin B., and Wagner P.D. (2002). Effect of blood haemoglobin on VO2MAX and cardiovascular function in lowlanders acclimatized to $5260 \mathrm{~m}$. J. Physiol. 545:715-728.

Forsythe J.A., Jiang B.-H., Iyer N.V., Agani F., Leung S.W., Koos R.D., and Semenza G.L. (1996). Activation of vascular endothelial growth factor gene transcription by hypoxia-inducible factor 1. Mol. Cell Biol. 16:4604-4613.

Garner S.H., Sutton J.R., Burse R.L., McComas A.J., Cymerman A., and Houston C.S. (1990). Operation Everest II: neuromuscular 
performance under conditions of extreme simulated altitude. J. Appl. Physiol. 68:1167-1172.

Green H.J., Sutton J.R., Cymerman A., Young P.M., and Houston C.S. (1989a). Operation Everest II: adaptations in human skeletal muscle. J. Appl. Physiol. 66:2454-2461.

Green H.J., Sutton J., Young P., Cymerman A., and Houston C.S. (1989b). Operation Everest II: muscle energetics during maximal exhaustive exercise. J. Appl. Physiol. 66:142-150.

Grocott M.P.W., Martin D.S., Wilson M.H., Mitchell K., Dhillon S., Mythen M.G., Montgomery H.E., and Levett D.Z.H. (2010). Caudwell Xtreme Everest. High Alt. Med. Biol. 11:XXX-XXX. Groves B.M., Reeves J.T., Sutton J.R., Wagner P.D., Cymerman A., Malconian M.K., Rock P.B., Young P.M., and Houston C.S. (1987). Operation Everest II: elevated high-altitude pulmonary resistance unresponsive to oxygen. J. Appl. Physiol. 63:521530.

Hogan M.C., Bebout D.E., and Wagner P.D. (1991). Effect of increased $\mathrm{Hb}-\mathrm{O} 2$ affinity on $\mathrm{VO} 2 \mathrm{max}$ at constant $\mathrm{O} 2$ delivery in dog muscle in situ. J. Appl. Physiol. 70:2656-2662.

Hornbein T.F., Townes B.D., Schoene R.B., Sutton J.R., and Houston C.S. (1989). The cost to the central nervous system of climbing to extremely high altitude. N. Engl. J. Med. 321: 1714-1719.

Houston C.S., Cymerman A., and Sutton J.R. (1991). Operation Everest II: Biomedical Studies During a Simulated Ascent of Mt. Everest. US Army Research Institute of Environmental Medicine, Natick, MA.

Kennedy R.S., Dunlap W.P., Banderet L.E., Smith M.G., and Houston C.S. (1989). Cognitive performance deficits in a simulated climb of Mt. Everest: Operation Everest II. Aviat. Space Environ. Med. 60:99-104.

Kobrick J.L., Crohn E., Shukitt B., Houston C.S., Sutton J.R., and Cymerman A. (1988). Operation Everest II: lack of an effect of extreme altitude on visual contrast sensitivity. Aviat. Space Environ. Med. 59:160-164.

MacDougall J.D., Green H.J., Sutton J.R., Coates G., Cymerman A., Young P., and Houston C.S. (1991). Operation Everest II: structural adaptations in skeletal muscle in response to extreme simulated altitude. Acta Physiol. Scand. 142:421-427.

Meehan R.T., Neale L.S., Kraus E.T., Stuart C.A., Smith M.L., Cintron N.M., and Sams C.F. (1992). Alterations in human mononuclear leukocytes following space flight. Immunology. 76:491-497.

Meehan R.T., Uchakin P.H., and Sams C.F. (2001). High altitude and human immune responsiveness. In: High Altitude: An Exploration of Human Adaptation. T. F. Hornbein and R. B. Schoene, eds. Marcel Dekker, New York; pp. 645-661.

Pugh L.G.C.E., Gill M.B., Lahiri S., Milledge J.S., Ward M.P., and West J.B. (1964). Muscular exercise at great altitudes. J. Appl. Physiol. 19:431-440.

Rahn H., and Otis A.B. (1949). Man's respiratory response during and after acclimatization to high altitude. Am. J. Physiol. 157:445-462.

Reeves J.T., Groves B.M., Sutton J.R., Wagner P.D., Cymerman A., Malconian M.K., Rock P.B., Young P.M., and Houston C.S. (1987). Operation Everest II: preservation of cardiac function at extreme altitude. J. Appl. Physiol. 63:531-539.

Richardson R.S., Tagore K., Haseler L., Jordan M., and Wagner P.D. (1998). Increased VO2max with a right shifted $\mathrm{Hb}-\mathrm{O} 2$ dissociation curve at a constant $\mathrm{O} 2$ delivery in dog muscle in situ. J. Appl. Physiol. 84:995-1002.

Roca J., Hogan M.C., Story D., Bebout D.E., Haab P., Gonzalez R., Ueno O., and Wagner P.D. (1989). Evidence for tissue diffusion limitation of VO2max in normal humans. J. Appl. Physiol. 67:291-299.
Rose M.S., Houston C.S., Fulco C.S., Coates G., Sutton J.R., and Cymerman A. (1988). Operation Everest II: nutrition and body composition. J. Appl. Physiol. 65:2545-2551.

Schoene R.B., Roach R.C., Hackettt P.H., Sutton J.R., Cymerman A., and Houston C.S. (1990). Operation Everest II: ventilatory adaptation during gradual decompression to extreme altitude. Med. Sci. Sports Exerc. 22:804-810.

Suarez J., Alexander J.K., and Houston C.S. (1987). Enhanced left ventricular systolic performance at high altitude during Operation Everest II. Am. J. Cardiol. 60:137-142.

Sutton J.R., Reeves J.T., Wagner P.D., Groves B.M., Cymerman A., Malconian M.K., Rock P.B., Young P.M., Walter S.D., and Houston C.S. (1988). Operation Everest II: oxygen transport during exercise at extreme simulated altitude. J. Appl. Physiol. 64:1309-1321.

Wagner P.D. (1996). Determinants of maximal oxygen transport and utilization. Annu. Rev. Physiol. 58:21-50.

Wagner P.D. (2001). Gas exchange. In: High Altitude: An Exploration of Human Adaptation. T. F. Hornbein and R. B. Schoene, eds. Marcel Dekker, New York; pp. 199-234.

Wagner P.D., Hedenstierna G., and Bylin G. (1987a). Ventilationperfusion inequality in chronic asthma. Am. Rev. Respir. Dis. 136:605-612.

Wagner P.D., Sutton J.R., Reeves J.T., Cymerman A., Groves B.M., and Malconian M.K. (1987b). Operation Everest II: pulmonary gas exchange during a simulated ascent of Mt. Everest. J. Appl. Physiol. 63:2348-2359.

West J.B. (2010). American Medical Research Expedition to Everest. High Alt. Med. Biol. 11:103-110.

West J.B., Lahiri S., Maret K.H., Peters R.M., and Pizzo P.J. (1983). Barometric pressures at extreme altitudes on Mt. Everest: physiological significance. J. Appl. Physiol. 54:1188-1194.

West J.B., and Wagner P.D. (1980). Predicted gas exchange on the summit of Mt. Everest. Respir. Physiol. 42:1-16.

Winslow R.M., Samaja M., and West J.B. (1984). Red cell function at extreme altitude on Mount Everest. J. Appl. Physiol. Respir. Environ. Exerc. Physiol. 56:109-116.

Young P.M., Rose M.S., Sutton J.R., Green H.J., Cymerman A., and Houston C.S. (1989). Operation Everest II: plasma lipid and hormonal responses during a simulated ascent of Mt. Everest. J. Appl. Physiol. 66:1430-1435.

\section{Additional Publications Emanating from the OE II Expedition}

\section{Original research}

Andrew M., O’Brodovich H., and Sutton J. (1987). Operation Everest II: coagulation system during prolonged decompression to 282 torr. J. Appl. Physiol. 63:1262-1267.

Anholm J.D., Powles A.C., Downey R. 3rd, Houston C.S., Sutton J.R., Bonnet M.H., and Cymerman A. (1992). Operation Everest II: arterial oxygen saturation and sleep at extreme simulated altitude. Am. Rev. Respir. Dis. 145(4 Pt. 1):817-826.

Cymerman A., Reeves J.T., Sutton J.R., Rock P.B., Groves B.M., Malconian M.K., Young P.M., Wagner P.D., and Houston C.S. (1989). Operation Everest II: maximal oxygen uptake at extreme altitude. J. Appl. Physiol. 66:2446-2453.

Forte V.A. Jr., Malconian M.K., Burse R.L., Rock P.B., Young P.M., Trad L.A., Ruscio B.A., Sutton J.R., Houston C.S., and Cymerman A. (1989). Operation Everest II: comparison of four instruments for measuring blood O2 saturation. J. Appl. Physiol. 67:2135-2140.

Malconian M., Hultgren H., Nitta M., Anholm J., Houston C., and Fails H. (1990) The sleep electrocardiogram at extreme altitudes (Operation Everest II). Am. J. Cardiol. 65:1014-1020. 
Malconian M., Rock P., Hultgren H., Donner H., Cymerman A., Groves B., Reeves J., Alexander J., Sutton J., Nitta M., et al. (1990). The electrocardiogram at rest and exercise during a simulated ascent of Mt. Everest (Operation Everest II). Am. J. Cardiol. 65:1475-1480.

Malconian M.K., Rock P., Devine J., Cymerman A., Sutton J.R., and Houston C.S. (1987). Operation Everest II: Altitude decompression sickness during repeated altitude exposure. Aviat. Space Environ. Med. 58:679-682.

Malconian M.K., Rock P.B., Reeves J.T., Cymerman A., and Houston C.S. (1993). Operation Everest II: gas tensions in expired air and arterial blood at extreme altitude. Aviat. Space Environ. Med. 64:37-42.

Reeves J.T., Groves B.M., Cymerman A., Sutton J.R., Wagner P.D., Turkevich D., and Houston C.S. (1990). Operation Everest II: cardiac filling pressures during cycle exercise at sea level. Respir. Physiol. 80:147-154.

Reeves J.T., Groves B.M., Sutton J.R., Wagner P.D., Cymerman A., Malconian M.K., Rock P.B., Young P.M., Alexander J.K., and Houston C.S. (1987). Oxygen transport during exercise at extreme altitude: Operation Everest II. Ann. Emerg. Med. 16:993-998.

Reeves J.T., Linehan J.H., and Stenmark K.R. (2005). Distensibility of the normal human lung circulation during exercise. Am. J. Physiol. Lung Cell. Mol. Physiol. 288:L419-L425.

Wagner P.D., Wagner H.E., Groves B.M., Cymerman A., and Houston C.S. (2007). Hemoglobin P50 during a simulated ascent of Mt. Everest, Operation Everest II. High Alt. Med. Biol. 8:32-42.

Welsh C.H., Wagner P.D., Reeves J.T., Lynch D., Cink T.M., Armstrong J., Malconian M.K., Rock P.B., and Houston C.S. (1993). Operation Everest. II: spirometric and radiographic changes in acclimatized humans at simulated high altitudes. Am. Rev. Respir. Dis. 147:1239-1244.

Yamamoto Y., Hughson R.L., Sutton J.R., Houston C.S., Cymerman A., Fallen E.L., and Kamath M.V. (1993). Operation Everest II: an indication of deterministic chaos in human heart rate variability at simulated extreme altitude. Biol. Cybern. 69:205-212.
Young P.M., Sutton J.R., Green H.J., Reeves J.T., Rock P.B., Houston C.S., and Cymerman A. (1992). Operation Everest II: metabolic and hormonal responses to incremental exercise to exhaustion. J. Appl. Physiol. 73:2574-2579.

\section{Reviews}

Houston C.S., Sutton J.R., Cymerman A., and Reeves J.T. (1987). Operation Everest II: man at extreme altitude. J. Appl. Physiol. 63:877-882.

Reeves J.T., Houston C.S., and Sutton J.R. (1989). Operation Everest II: resistance and susceptibility to chronic hypoxia in man. J. Royal Soc. Med. 82:513-514.

Reeves J.T., Wolfel E.E., Green H.J., Mazzeo R.S., Young A.J., Sutton J.R., and Brooks G.A. (1992). Oxygen transport during exercise at altitude and the lactate paradox: lessons from Operation Everest II and Pikes Peak. Exerc. Sport Sci. Rev. 20:275-296.

Sutton J.R., Maher J.T., and Houston C.S. (1983). Operation Everest II. Prog. Clin. Biol. Res. 136:221-233.

Sutton J.R., Reeves J.T., Groves B.M., Wagner P.D., Alexander J.K., Hultgren H.N., Cymerman A., and Houston C.S. (1992). Oxygen transport and cardiovascular function at extreme altitude: lessons from Operation Everest II. Int. J. Sports Med. 13(Suppl. 1):S13-S18.

Address correspondence to:

Peter D. Wagner, MD

Division of Physiology, Department of Medicine University of California, San Diego 9500 Gilman Drive La Jolla, CA 92093-0623

E-mail: pdwagner@ucsd.edu

Received November 23, 2009; accepted in final form March 17, 2010. 
